DOI 10.37882/2223-2982.2021.01.17

\title{
ПОКАЗАТЕЛИ ЛУЧШИХ ПРАКТИК СУБЪЕКТОВ РОССИЙСКОЙ ФЕДЕРАЦИИ ПО ОРГАНИЗАЦИИ ЦЕНТРОВ ОКАЗАНИЯ ПСИХОЛОГО-ПЕДАГОГИЧЕСКОЙ ПОМОЩИ РОДИТЕЛЯМ С ДЕТЬМИ ДОШКОЛЬНОГО ВОЗРАСТА
}

\section{INDICATORS OF THE BEST \\ PRACTITIONERS OF THE RUSSIAN \\ FEDERATION IN THE PROVISION \\ OF PSYCHOLOGICAL AND EDUCATIONAL \\ ASSISTANCE TO PARENTS \\ WITH CHILDREN OF PRESCHOOL AGE}

S. Kurnosova

Summary: This paper substantiates the need to provide parents of children of preschool age, in particular, under the age of three, with diagnostic, psychological, pedagogical and consulting assistance at the state level. Within the framework of the article, the list of acts of pre-school educational organizations that make up the regulatory framework, within which it is necessary to solve the problem, is studied and analyzed. As a way to resolve it, the creation and maintenance of variable forms of preschool education is considered. The main difficulties of the development of a network of alternative educational preschool organizations are studied, their main functions are indicated.

The work contains practical materials on the development of a system of indicators of the best practices of organizing alternative centers, which resulted, firstly, the creation of a set of indicators of the best practices of organizing diagnostic, psychological-pedagogical and counseling centers for parents with children of preschool age in the regions of the Russian Federation, secondly, The selection of best practices in the organization of centers has been carried out.

Keywords: center of psychological and pedagogical assistance, children of preschool age, indicators of best practices of care, best practices of the organization of centers.

\author{
Курносова Светлана Анатольевна \\ Д.п.н., доцент, Московский педагогический \\ государственный университет \\ sa.kurnosova@mpgu.edu
}

Аннотация: В данной работе обосновывается необходимость оказания родителям детей дошкольного возраста, в частности в возрасте до трех лет, диагностической, психолого-педагогической и консультационной помощи на государственном уровне. В рамках статьи изучен и проанализирован перечень актов дошкольных образовательных организаций, составляющих нормативную базу, в рамках которой необходимо решать проблему. В качестве пути ее разрешения рассматривается создание и поддержание вариативных форм дошкольного образования. Изучены основные трудности развития сети альтернативных образовательных дошкольных организаций, обозначены их основные функции.

Работа содержит практические материалы по разработке системы показателей лучших практик организации альтернативных центров, результатом которых являлось, во-первых, создание совокупности показателей лучших практик организации в регионах РФ центров диагностической, психолого-педагогической и консультативной помощи родителям с детьми дошкольного возраста, во-вторых, осуществлён выбор лучших практик по организации центров.

Ключевые слова: центр оказания психолого-педагогической помощи, дети дошкольного возраста, показатели лучших практик помощи, лучшие практики организации центров.

\footnotetext{
C егодня для процесса воспитания подрастающего поколения характерен ряд проблем, среди которых наиболее острыми являются рост количества детей, имеющих особые образовательные потребности, выраженный дефицит мест в дошкольных образовательных учреждениях, недостаточная психолого-педагогическая компетентность родителей. В этих условиях как никогда актуальной становится необходимость оказания родителям детей дошкольного возраста, в частности в возрасте до трех лет, диагностической, психолого-педагогической и консультационной помощи на государственном уровне.
}

Итак, родители нуждаются в помощи квалифицированных специалистов. В первую очередь речь идет о родителях тех детей, которые по тем или иным причинам не могут посещать дошкольное образовательное учреждение. Начинать изучение обозначенной проблемы следует с выяснения степени разработанности на уровне государства проблемы организации центров, оказывающих психолого-педагогическую помощь родителям детей дошкольного возраста.

Анализ информативных источников (актов дошкольных образовательных организаций локального, 
регионального и федерального уровня) указывает на следующую нормативную базу, которой необходимо руководствоваться при решении проблемы, а именно:

- Положениями о консультативных пунктах в ДОУ;

- Программой внедрения в службах моделей оказания диагностической, психолого-педагогической и консультативной помощи родителям детей, находящихся в дошкольном возрасте, в том числе до трех лет, и не посещающих дошкольные образовательные организации;

- Приказом Министерства науки и высшего образования РФ от 17 октября 2013 г. №1155;

- Федеральным государственным образовательным стандартом дошкольного образования;

- Указом Президента РФ от 1 июня 2012 г. № 761 «О Национальной стратегии действий в интересах детей на 2012 - 2017 годы»;

- Федеральным законом от 29 декабря 2012 года № 273-Ф3 «Об образовании в Российской Федерации».

Из анализа нормативных актов можно сделать вывод о значимости возрастного периода до трех лет с позиции развития ребенка. В первую очередь данное высказывание справедливо для развития личностного потенциала, освоения базовых навыков социализации и поддержания здоровья ребенка. Необходимым условием для обеспечения благоприятной среды развития ребенка дошкольного возраста является доступность и открытость качественных образовательных услуг, предоставляемых государством.

Вследствие недостатка мест в государственных образовательных дошкольных учреждениях появилась четко выраженная необходимость в создании и поддержании вариативных форм дошкольного образования, способных оказывать ощутимую помощь родителям в развитии и воспитании ребенка, а также в методическом и нормативном обеспечении образовательного процесса наравне с традиционной формой дошкольных учреждений [4]. Важно продолжать активно развивать вариативные формы дошкольного образования, к которым относятся центры игровой поддержки, группы кратковременного пребывания, семейные группы, консультативные пункты, центры оказания диагностической, психолого-педагогической и консультативной помощи родителям детей дошкольного возраста и так далее [1, с. 113], [4].

В качестве основной цели деятельности центров, оказывающих психолого-педагогическую помощь родителям детей дошкольного возраста, необходимо признавать обеспечение преемственности и единства общественного и семейного воспитания, а также оказание диагностической и методической помощи семье в процессе поддержания здорового психического и конструктивного социального развития ребёнка [5; 7].
На консультативный центр возлагается решение задач, связанных с оказанием всесторонней помощи родителям с детьми, не посещающими дошкольные образовательные учреждения, во-первых, в вопросах обеспечения равных стартовых возможностей при поступлении в школу, во-вторых, в вопросах оказания консультативной помощи родителям в развитии, обучении и воспитании детей дошкольного возраста, в-третьих, в вопросах проведения комплексной профилактики отклонений психического, физического и социального характера. Работа консультативного центра должна быть направлена на обеспечение максимального сокращения социальной изоляции семей с детьми, которые не посещают детский сад $[2 ; 5 ; 7]$.

Сегодня развитие достаточной сети консультативных центров сопровождается рядом проблем, связанных с недостатком ресурсных возможностей научно-методического сопровождения образовательной и воспитательной деятельности. Специалисты центров испытывают потребность экспертно-консультационного сопровождения их деятельности [3].

На основе анализа материалов, которые размещены на Информационной платформе сопровождения деятельности консультационных центров системы дошкольного образования России, представляется возможной разработка системы показателей лучших практик организации альтернативных центров [1, с. 39-42]. В основе таковой системы показателей лежат проанализированные материалы деятельности двадцати одной организации в восьми субъектах. Проанализированные организации являются обладателями грантов по мероприятию 2.1. ФЦПРО в 2016-2017 годах. Также в рамках анализа была изучена деятельность иных образовательных организаций, в рамках которых функционируют центры [1, с. 52].

Выбор лучших практик осуществлялся поэтапно: во-первых, выбирались показатели лучших практик по организации центров; во-вторых, осуществлялся отбор регионов с лучшими практиками по организации центров; в-третьих, проводился опрос работников центров и выявлялись ключевые элементы успешной работы; в-четвёртых, собиралась информация от экспертов.

Первый этап - выбор показателей для выявления лучших практик.

Все показатели были объединены в 4 группы: в первую группу вошли показатели на основе разработанной системы нормативно-правовых условий; во вторую группу - на основе разработанной системы повышения квалификации сотрудников центра; третья группа показателей была объединена на основе системы материально-технических условий центра; показатели четвёр- 
той группы были объединены на основе разработанной системы научно-методической поддержки родителей с детьми дошкольного возраста, в том числе в возрасте до трех лет.

Основной показатель первой группы («Система нормативно-правовых условий центра») заключается в наличии разработанных или доработанных методических и правовых документов, которые регламентируют формирование, организацию и развитие модели деятельности центра.

К группе «Система повышения квалификации сотрудников центра» был отнесен следующий ряд показателей:

- степень удовлетворённости специалистов центра профессиональной деятельностью в рамках действующей модели;

- повышение квалификации сотрудников (в первую очередь, узкопрофильных специалистов);

- развитие системы стимулирования труда посредством материальных и нематериальных поощрений;

- научно-методическое обеспечение деятельности специалистов;

- проведение всероссийских, межрегиональных и региональных круглых столов, семинаров и конференций, которые обеспечивают широкое представительство специалистов центра;

- сетевое взаимодействие с образовательными организациями при научно-методической поддержке специалистов.

Группа «Система диагностической, психолого-педагогической и консультативной помощи родителям детей дошкольного возраста, в том числе до трех лет» включает в себя следующие показатели:

- степень удовлетворённости родителей полученными услугами;

- разработка дидактических и методических материалов, а также авторских программ по направлениям деятельности центра.

Группа критериев «Система материально-технических условий центра» включает следующие основные показатели:

- организационные расходы на мероприятия по обсуждению практики и проблематики работы центра;

- дооснащение центра (специальными техническими средствами обучения и учебной литературой) по направлениям деятельности центра.

Второй этап - выбор регионов, представляющих лучшие практики организации центров (служб), происходил на основе анализа результатов рейтинга, экспертных оценок и результатов анкетирования.
По результатам итогового рейтинга лидеры были выявлены в следующих регионах [1, с. 67]:

- Республика Бурятия (Сибирский федеральный округ, МАДОУ «Центр развития ребенка № 86 Детский сад "ОЮНА"», г. Улан-Удэ);

- Мурманская область (Северо-Западный федеральный округ, МБДОУ «Детский сад № 8 комбинированного вида», г. Североморск);

- Нижегородская область (Приволжский федеральный округ, КЦ ЧДОУ «Центр «ДИВО», г. Нижний Новгород);

- Новосибирская область (Сибирский федеральный округ, МАДОУ «Детский сад компенсирующего вида № 23 «Дельфинчик», г. Искитим);

- Республика Татарстан (Приволжский федеральный округ, МБДОУ «Детский сад № 151 комбинированного вида», г. Казань; Детский сад общеразвивающего вида с приоритетным осуществлением деятельности по художественно-эстетическому направлению развития воспитанников № 95 «Балкыш», г. Набережные Челны);

- Республика Чувашия (Приволжский федеральный округ, МБДОУ «Детский сад № 201 «Островок детства», г. Чебоксары; МАДОУ «Детский сад № 7 «Созвездие», г. Чебоксары);

- Ямало-Ненецкий автономный округ (Уральский федеральный округ, МДОУ «Детский сад «Ёлочка», г. Надым).

Третий этап - проведение опроса с целью выявления ключевых элементов успешной работы центров.

Были определены конкретные мероприятия, используемые регионами с лучшими практиками организации центров. Выбор показателей для выявления лучших практик по организации центров осуществлялся на основе анализа материалов информационной платформы сопровождения деятельности консультационных центров системы дошкольного образования России в разделах «Форма предложений и замечаний в отношении эффективности использования моделей» и «Анкета опроса сотрудников центра». В опросе приняли участие организации восьми субъектов РФ: обладатели грантов по мероприятию 2.1. ФЦПРО в 2016-2017 годах и иные образовательные организаций, в рамках которых функционируют центры.

Четвёртый этап - сбор информации от экспертов.

Выбор показателей для выявления лучших практик по организации центров осуществлялся на основе экспертной оценки материалов, которые размещены на информационной платформе сопровождения деятельности консультационных центров системы дошкольного образования России в личных кабинетах центров, в разделах: «Информация о центре, службе», «План меропри- 
ятий по внедрению моделей», «План-график внедрения модели», «План реализации экспериментального (инновационного) проекта», «Описание условий для функционирования консультационного центра по выбранной модели», «Сетевое взаимодействие в рамках деятельности центра», «Психолого-педагогическая, консультационная, диагностическая помощь родителям с детьми дошкольного возраста, в том числе от 0 до 3 лет».

Таким образом, в результате проведенного исследования была разработана система показателей лучших практик организации в регионах Российской Федерации центров диагностической, психолого-педагогической и консультативной помощи родителям детей дошкольного возраста; осуществлён выбор лучших практик по организации центров: выбраны показатели для выявления лучших практик и регионы-носители лучших практик; с целью выявления ключевых элементов успеха проведён опрос специалистов центров; собрана и обобщена информация от экспертов.

Материалы лучших практик работы центров пред- ставлены в сборнике «Лучшие практики субъектов Российской Федерации по развертыванию сети центров (служб) оказания психолого-педагогической, диагностической и консультативной помощи родителям с детьми дошкольного возраста, в том числе от 0 до 3 лет, и детьми с особыми образовательными потребностями» $[1$, c. 76$]$.

Результаты выполненных работ могут быть использованы руководителями и педагогическими работниками дошкольных образовательных организаций при разработке программ развития организаций; профессиональных образовательных организаций и образовательных организаций высшего образования при разработке образовательных программ подготовки будущих педагогов; специалистами органов управления образования при отборе стажировочных площадок, разрабатывающих и реализующих модель оказания психолого-педагогической помощи родителям с детьми дошкольного возраста; при оценке эффективности реализации данной модели.

\section{ЛИТЕРАТУРА}

1. Лучшие практики субъектов Российской Федерации по развертыванию сети центров (служб) оказания психолого-педагогической, диагностической и консультативной помощи родителям с детьми дошкольного возраста, в том числе от 0 до 3 лет, и детьми с особыми образовательными потребностями. М.: Федеральный институт развития образования. 2017. 414 с.

2. Модели организации деятельности консультационных центров по оказанию психолого-педагогической, диагностической и консультативной помощи родителям с детьми от 0 до 3 лет. [Электронный ресурс]. Режим доступа: http://odo.detkin-club.ru/editor/2113/files/43aa9d8620caaa130015853e0586d85d. pdf (дата обращения: 18.08.2017).

3. Пентина Е.В., Рубцова А.В. Система работы консультативного центра «Я - компетентный родитель». Из опыта работы. [Электронный ресурс]. Режим доступа: http://detstvogid.ru/sistema-rabotyi-konsultativnogo-tsentra-ya-kompetentnyiy-roditel/.html (дата обращения: 18.08.2017).

4. Письмо Минобрнауки РФ от 31.01.2008 № 03-133 «0 внедрении различных моделей обеспечения равных стартовых возможностей получения общего образования для детей из разных социальных групп и слоев населения». [Электронный ресурс]. Режим доступа: https://www.lawmix.ru/expertlaw/66776 (дата обращения: 18.08.2017).

5. Тарасова Н.В. Модели организации деятельности консультационных центров по оказанию психолого-педагогической, диагностической и консультативной помощи родителям с детьми от 0 до 3 лет, преимущественно не посещающих дошкольную образовательную организацию [Электронный ресурс]. Режим доступа: http://www.firo.ru/wp-content/uploads/2016/08/Tarasova_tez.pdf (дата обращения: 06.04.2019).

6. Тендер: Выполнение работ в рамках проекта «Разработка алгоритма и программы создания, функционирования и сопровождения в субъектах Российской Федерации служб (центров) психолого-педагогической, диагностической, консультационной помощи родителям с детьми дошкольного возраста, в том числе от 0 до 3 лет». [Электронный ресурс]. Режим доступа: http://rostender.info/region/moskva-gorod/28469438-tender-vypolnenie-rabot-v-ramkahproekta-razrabotka-algoritma-i-programmy-sozdaniya-funkcionirovaniya-i-soprovojdeniya-v-subektah-rossijskoj (дата обращения: 06.04.2019).

7. Требования к организации центра (службы) по оказанию психолого-педагогической, диагностической и консультативной помощи родителям с детьми дошкольного возраста, в т.ч. от 0 до 3 лет. [Электронный ресурс]. http://www.firo.ru/wp-content/uploads/2016/08/\%D0\%A2\%D1\%80\%D0\%B5\%D0\%B1 \%D0\%BE\%D0\%B2\%D0\%B0\%D0\%BD\%D0\%B8\%D1\%8F-\%D0\%BA-\%D0\%BE\%D1\%80\%D0\%B3\%D0\%B0\%D0\%BD\%D0\%B8\%D0\%B7\%D0\%B0\%D1\%86\%D0 \%B8\%D0\%B8-\%D0\%A6\%D0\%B5\%D0\%BD\%D1\%82\%D1\%80\%D0\%B0.pdf (дата обращения: 06.04.2019).

(c) Курносова Светлана Анатольевна (sa.kurnosova@mpgu.edu). 